\title{
Understanding the concept of the $\mathrm{Pi}(\boldsymbol{\pi})$ number for pre-service teacher
}

\author{
Yus Mochamad Cholily ${ }^{1}$, Beti Istanti Suwandayani ${ }^{2}$ \\ ${ }^{1}$ Departement of Mathematics Education, University of Muhammadiyah Malang, Indonesia \\ ${ }^{2}$ Department of Primary School Teacher Education, University of Muhammadiyah Malang, Indonesia
}

\section{Article Info \\ Article history: \\ Received Feb 2, 2021 \\ Revised Aug 18, 2021 \\ Accepted Sep 10, 2021}

\section{Keywords:}

Elementary school

$\mathrm{Pi}(\pi)$

Pre-service teacher

\begin{abstract}
This study examined the learning of Pi $(\pi)$ numbers in elementary school mathematics. This research was conducted by employing case study method containing a single case concerning the Pi $(\pi)$ numbers. A total of 432 preservice teachers participated in the study from the academic year of 20192020. This research employed observation, interview, and document analysis as the data collection tool. The conduct of the research involving the teachers and pre-service teachers was made in the classroom environment. The practice that participants posed for the account of $\mathrm{Pi}(\pi)$ number were analyzed by descriptive analysis technique in the scope of qualitative analysis. The data obtained from the participants were summarized and interpreted according to the predefined theme, and findings were arranged by a direct citation of the problems. Based on the analysis of the research, it showed that participants had problems in determining Pi $(\pi)$ numbers as $\mathrm{Pi}$ $(\pi)$ numbers are only taught by memorization methods. The teachers also did not understand about the source of Pi $(\pi)$ number. Learning Pi $(\pi)$ numbers are directly practiced through problems and formulas. Understanding the formula of plane figures is also not yet understood, so teachers and students basically only memorize the formula.
\end{abstract}

This is an open access article under the CC BY-SA license.

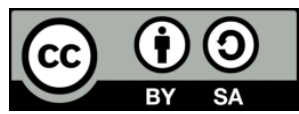

\section{Corresponding Author:}

Beti Istanti Suwandayani

Department of Primary School Teacher Education

University of Muhammadiyah Malang

Tlogomas Street, 246 Malang, 65154, Indonesia

Email: beti@umm.ac.id

\section{INTRODUCTION}

Mathematics in elementary school consists of several materials. One of them is geometry [1]-[4]. In geometry there is the number $\mathrm{Pi}(\pi) 3.14$ or $\frac{22}{7}$. Understanding of concepts in learning mathematics is one of the keys to the provision of mathematical abilities in students. The large number of symbols and formulas used in learning mathematics causes most students to assume that mathematics is a difficult and unpleasant lesson [5]-[9]. This happens because students are not given the opportunity to know how the process of the symbols and values that usually accompany the symbol. Students only use symbols in the finished form so they do not understand the meaning of the symbols.

The main tool for learning mathematics and the purpose of learning mathematics is through problem solving. With problem solving is an inseparable part of the process of learning mathematics. In learning mathematics need conceptual development of formulas not just giving formulas to students because when students develop formula, they gain a conceptual understanding of the relationships that exist and can be directly involved in a real process of working mathematics [10]-[12]. This can help students understand 
where formulas are created and not view formulas as mysterious, tend to remember them, and become more convinced that mathematics makes sense. The mere use of formulas from books does not provide the development of relationships between these formulas. Concepts in mathematics which are arranged in stages and sequentially still require special evidences. So, in learning mathematics, the previous concept must be mastered because it is a prerequisite for continuing the next concept [13], [14]. Teaching mathematics effectively requires an understanding of what students know and need to learn and then provides challenges and support so they can learn mathematics well.

Based on the ranking of data from Programme for International Student Assessment (PISA) in 2018, education in Indonesia is declining in rank again [15]-[18]. The value of the indicators of students' reading, mathematics, and science or science skills has dropped. This shows that Indonesia's position is ranked 72nd among 77 countries. The ability of mathematics declining from 386 points to 379 points [19]. Problems in the field of mathematics have an impact on the competitiveness of human resources in the future. Wilkins [20] states, "a person's mathematical disposition related to her or his beliefs about and attitude toward mathematics may be as important as content knowledge for making informed decisions in terms of willingness to use this knowledge in everyday life." This means that student learn disposition towards mathematics has the opportunity to be a factor that determines student success in learning mathematics. Disposition is also formed, if the other components have developed well previously.

Curriculum change in a short period time in Indonesia has caused the unloading of curriculum pairs [21]-[23]. Indonesian 2013 curriculum has been applied in Indonesia since 2013 [24], in practice in the field, there are still many rural areas of Indonesia that still do not practice the educational unit lever curriculum that is the curriculum before the 2013 curriculum. The emphasis of this curriculum is the balance of soft and hard skills covering aspects of attitude, skills and knowledge [25]-[27]. The concept of the 2013 curriculum is the objective character or competence of graduates who are classed in the form of integration by emphasizing character education, learning character which emphasizes the scientific approach with a more detailed assessment character by emphasizing the assessment process [27]-[30].

Integrative thematic learning in the 2013 curriculum is applied to basic education by integrating several lessons that have the same scope. However, the facts at school show many teachers have not yet fully implemented the 2013 National Curriculum which has the principle of integrating many materials. The aim of exploration in thematic learning is so that students are able to do better on the stages in scientific thinking. There are some compulsory subjects in elementary school. One of which is mathematics. Mathematics is a universal science that underlies the development of modern technology today. Because mathematics has an important role that becomes a mean in solving life problems [31]. The development of reasoning and thinking skills is important from the elementary school level to the tertiary level [32]-[34]. Elementary school students must understand the concept of mathematics, so that this becomes the basis for developing mathematics communication at the next level.

Evidencing is often conducted in the field of mathematics. In general, there are still many teachers who do not know the method used to carry out evidencing in mathematics. Speaking of mathematical evidence, sometimes we meet various groups, generally students and students who tend to think that evidence is not so important in learning mathematics [35], [36]. In the early stages of mathematical evidencing, it was not an easy practice. This problem is the cause that makes one lazy to understand the evidence in mathematics [37]-[40]. Among students, evidence is a tool that is only used by mathematicians to explain mathematical statements that are known to be true. In mathematical evidence, there are several simple methods of evidencing using basic logic rules, for example direct evidence, indirect evidence, evidence with contradiction, evidence of singularity, refutation of evidence with counter example, evidence by mathematical induction [41]. The evidence used can be in the form of formal evidence and informal evidence.

Numbers are the core material in mathematics especially in elementary education [42], [43]. Understanding the concept of numbers correctly is necessary for the sustainability of learning mathematics. In general, the concept of numbers in elementary school is integers [44]. But in its development, students are introduced to the concept of rational numbers which are numbers that can be written as meaningful comparisons between two integers. In line with the circle material in Geometry, pi, a number that is not a rational number is needed because this number is significant for the discussion of the area of a circle. In reality, the teacher is introducing pi numbers as a form of approach with rational numbers, Pi $(\pi)$. Learning is generally given doctrinally by utilizing $\mathrm{Pi}(\pi)$. This doctrine is strongly attached to students and is difficult to remove. Learning irrational numbers for the next level often has difficulty. The 2013 curriculum through a scientific approach can be used actually to introduce pi numbers correctly. The teacher's understanding of the inductive approach to the scientific learning model can be used to introduce the concept of Pi correctly.

$\mathrm{Pi}(\pi)$ is a symbol used by mathematicians to represent the ratio of the circumference of a circle to its diameter [45]-[47]. Pi is written in the small Greek letter $\pi$, spelled as pi, and comes from the first letter of 
the Greek word perimetros, which means circumference. Pi $(\pi)$ is an irrational number, meaning that the number cannot be written as the ratio/comparison of two integers. Fraction like $\frac{22}{7}$ generally used to estimate (approximation) of $\pi$ [48], [49], but no ordinary fraction (ratio of integers) can be an exact value. Since the time of the Babylonians, humans have been fascinated by mathematics shape which is considered as a perfect shape, which is a circle. Circles are certainly no stranger as circles occur naturally in the universe, ranging from water ripples to the circumference of moonlight. In nature, a circle often forms when a flat surface is affected by a force that works evenly in all directions. For example, when a marble falls into the water and produces waves that spread evenly in all directions as a series of circular ripples.

There are five characteristics of a mathematical approach [50]-[53]. First, the lesson uses real problem at the beginning of the lesson. Second, students use their own models or symbols to represent real problems. Third, use students' own contributions in solving problems and negotiating their strategies. Fourth, there are interactions between students facilitated by the teacher. Fifth, linking (intertwinement) mathematical topics with other mathematical topics or other lessons.

The students were given the opportunity to build and develop their ideas and thoughts when constructing mathematics [54], [55]. Teachers can choose appropriate learning activities as a basis to stimulate students to think and act when constructing these mathematical concepts. The learning steps are developed based on theoretical studies that pay attention to the basic principles and characteristics in learning with a realistic mathematical approach. Learning steps are made with the aim of facilitating the teacher in the learning process so that learning becomes more systematic and meaningful in accordance with the adopted theory. However, these steps do not limit teachers' space but can be developed according to the needs of the class. The purpose of this study was to understand how teachers teaching $\mathrm{Pi}(\pi)$ in learning mathematics of primary education.

\section{RESEARCH METHOD}

This research was carried out using the case study approach and contained a single case. This model is used because the present study investigated the mathematics teachers and pre service teachers' $\mathrm{Pi}$ $(\pi)$ numbers. It is understood that $\mathrm{Pi}(\pi)$ numbers are important factors in calculate the circumference and area of a circle. In this respect, mathematics teachers should have theoretical knowledge about Pi $(\pi)$ numbers. In the relevant literature, various quantitative studies have been conducted on the Pi $(\pi)$ numbers [56], [57]. In this study, the Pi $(\pi)$ numbers of mathematics teachers and pre-service teachers were discussed with a qualitative approach. Examining the mathematics teacher and pre-service teachers' $\mathrm{Pi}(\pi)$ numbers skills together and making comparisons reveal the important and original dimensions of this study.

This research was carried out under the Pi $(\pi)$ numbers. The population in this study totaling 432 people that pursued on Teacher Professional Program on Faculty of Teacher Training and Education, Muhammadiyah Malang of University. The sample on this study selected through a random sampling technique. Teacher Professional Program was such as teaching methods, material development, teaching practice, are considered as mathematics education program and graduates should be professional teacher. In the study participants in the research would describe the Pi $(\pi)$ numbers and how to teach Pi $(\pi)$ numbers for students on elementary school. The practice that participants posed for account $\mathrm{Pi}(\pi)$ number were analyzed by descriptive analysis. The data obtained from participants were summarized and interpreted according to the predefined theme and, findings were arranged by a direct citation of the problems [58].

This research was conducted in Pi $(\pi)$ numbers that participants enrolled as a part of their Teacher Professional Program. Teacher and pre service teachers did not have any interaction with each other. Program processes were conducted at different times and environment. The research was conducted by the researched in a classroom setting and during a semester of one hour a week, theoretical information was given firstly and then they were asked to make various applications both inside classroom. The expectation at the end of this program was that the knowledge, skills and experience of $\mathrm{Pi}(\pi)$ numbers of teachers and pre-service teachers were developed. Participants were expected to develop Pi $(\pi)$ numbers teaching skills. Table 1 provides explanations for what was done in the Pi $(\pi)$ numbers of mathematic learning. 
Table 1. Pi $(\pi)$ concept understanding instrument

\begin{tabular}{ll}
\hline \multicolumn{1}{c}{ Main category } & \multicolumn{1}{c}{ Indicators } \\
\hline How the pre-service teaching the Pi $(\pi)$ & $\begin{array}{l}\text { Preparing the lesson plan } \\
\text { numbers }\end{array}$ \\
The aims the lesson clearly \\
The lesson activity appears \\
Explain the central point and diameter & $\begin{array}{l}\text { They can understand the central point. } \\
\text { They are able to compare the finger and diameter. } \\
\text { They can identify the diameter. }\end{array}$ \\
& $\begin{array}{l}\text { They are able to draw the perfect circle. } \\
\text { They can measure the circumference of the circle using a string and a ruler. }\end{array}$ \\
Measure the circumference the circle & They can compare the perimeter by measuring with a thread and a ruler. \\
Using the circle rivet formula & They are able to find the formula \\
& They can find the magnitude of the Pi number \\
\hline
\end{tabular}

In this research, the data were taken from the observation, in-depth interview and documentation. The researcher is serving as the main instrument in this research, while the supporting instruments are the observation guide and interview guide. Researcher also observed the lesson activities in the class. Furthermore, researchers conducted interviews with the selected research subjects. The high level of validity, among other researchers involved in the lives of participants for a long time and trying to confirm and clarify the data obtained with the participants or conduct panel discussions with experts to re-analyze the data that was obtained. Other activities are conducting in-depth observations to photograph the best possible social phenomena under study such as reality. Furthermore, researchers increase dependability (reliability) by choosing the right method to achieve research objectives. The data in this study obtained from the written answers obtained after students completed the problem of understanding the concept Pi $(\pi)$ numbers and interviews were conducted by researchers. In this study, each interview was recorded by using a video and tape recorder. To ensure the validity and reliability of the research, data analysis was performed by triangulation through the display of data from the video and comparing it with observation data [59], [60].

To analyze the interview results, the researchers watched the interview video twice. When the researchers watched the video recording for the first time, they carefully paid attention to the relationship between the students' written test results and related literature. In the second view, the researchers looked in detail at the video interviews and the students' written test results to determine each category of the mental model level. After the categories of each mental model were determined, the next step was to begin to process the data according to the mental model levelling. This categorization is an important step in data analysis because it facilitates meaningful data interpretation. This categorization emerges through a literature review, identifying each interview answer and the students' written test that represents related concepts in the literature.

\section{RESULTS AND DISCUSSION}

Based on the observation data used in this study, teachers and prospective teachers who took part in the Professional Teacher Program were $20 \%$ of the teachers are above 35 years, $42 \%$ of teachers are $31-35$ years, while $38 \%$ were still under 35 years. This age range is reinforced by the results of interviews conducted with the Professional Teacher Program organizing committee that the participant who participated was a person appointed by the education office in their respective regional areas. Figure 1 shows the age distribution of research subjects, namely prospective elementary school teachers.

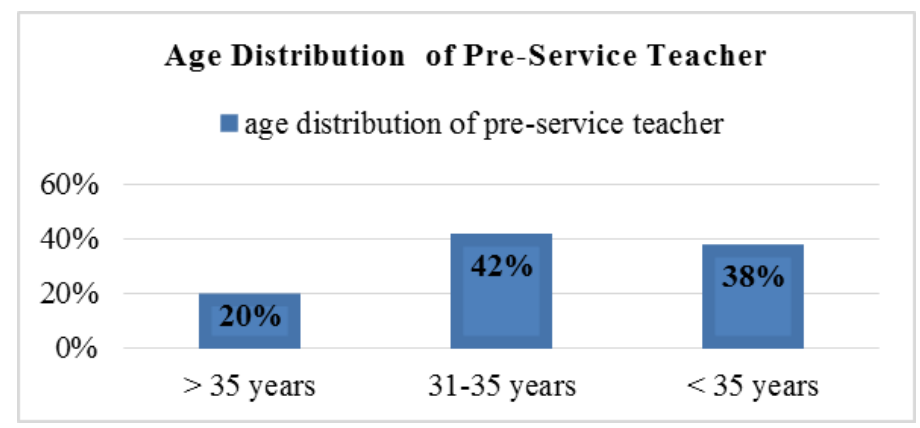

Figure 1. Age distribution of pre-service teacher 
The age distribution show that the high presentation of the age of pre service teacher are on 31-35 year. This age shows maturity in making decisions from what to choose. They are teachers who are required to be professional in teaching, but on the other hand the teacher still finds mathematics difficult. This can be shown in the interview transcript ( $\mathrm{R}$ is researcher; PST is per-service teacher).

$R \quad$ : "Why do you like mathematics subject?"

PST : "No, I don't like mathematics because it is difficult subject, so many formulas must be remembered. And my math grade is bad."

The dialogues indicate that the pre-service teachers do not like this exact subject. Although learning mathematics is a lot of formulas that must be learned. This is consistent with the results of observation in the work on environmental geomantic problems. The mathematics teachers and pre-service teachers have difficulty in working on these problems because they tend to memorize the formula. The documentation also shows that the teacher forgot the formula outside the circle correctly, so the results obtained were not right. $60 \%$ of mathematics teachers and pre-service teachers answered correctly because they still remembered and memorized the formula, while $40 \%$ answered incorrectly because they forgot the circle formula. $\mathrm{Pi}(\pi) 3.14$ or $\frac{22}{7}$, they get with the results of the transfer of knowledge, which is inherited from the previous teacher.

The results of the documentation also show that the teacher forgets the exact formula outside the circle, so the results obtained are not correct. As much as $60 \%$ of the mathematics teachers and pre-service teachers answered correctly because they still remembered and memorized the formula, while $40 \%$ answered incorrectly because they forgot the circle formula. Regarding the Pi $(\pi)$ number, they do not know the origin of the number. This is reinforced by the fact that the results of the interviews showed that they knew because they memorized the formula and the Pi $(\pi)$ number. They get the number Pi with the magnitude of Pi $(\pi) 3.14$ or $\frac{22}{7}$ only with the result of knowledge transfer, which is inherited from the previous teacher. This can be shown in the following interview transcript.

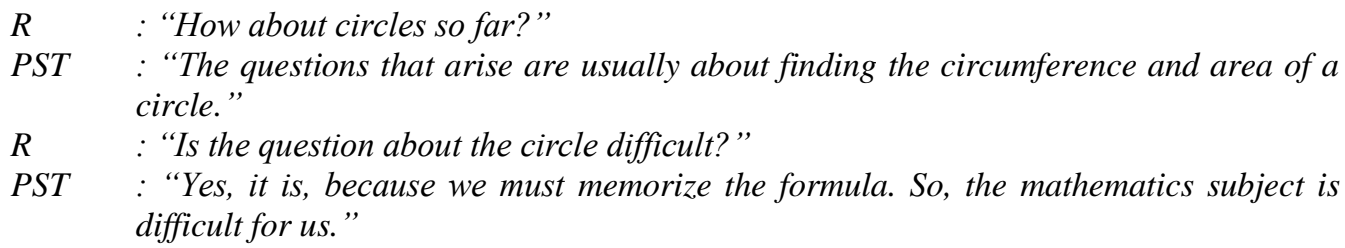

Learning mathematics is still considered a difficult subject. So that mathematics teachers and pre service teachers do not like this exact subject. Although learning mathematics, there are many formulas that must be learned [61]-[63]. This is in accordance with the results of the observations in the work on the geometry of the circle. The mathematics teachers and pre service teachers have difficulty working on these questions because they tend to memorize the formula.

In this section, the data obtained in this study were analyzed and presented with description. Mathematics is a tool of linguistic, logic, and statistical thinking. Mathematics is deductive, linguistic, and art science [64]. It is the core of sciences, the science of organized structure and pattern and relation sciences. Mathematics is called deductive science because it refuses generalization based on observation data, and experiments like other sciences. The general objective of mathematics learning in elementary school is to make the students able to solve mathematic problems. The learning process does not only focus on cognitive aspect, but also developing the students' ability in using mathematics in daily life. Thus, basic mathematics is essential for understanding mathematic materials. Based on the observation schedule on the implementation of mathematics learning in elementary schools, annual programs, semester programs, syllabus and lesson plan have been made. Participant of Teacher Professional Program have conducted teaching and learning processes by using the designed media. It showed that they had acted professionally. Teacher professionalism is a set of skills consisting of planning, implementing, and evaluating the learning process.

The implementation of mathematics learning showed that the learning process had also involved the students' mental optimally, not only making the students busy with listening, and taking note activities. The process of thinking was more emphasized. learning process is built dialogically and stimulant question and answer process is made to fix and increase the students' thinking ability [65]-[67]. The thinking ability could help them to construct their own knowledge. The teachers' role was not only giving information, but also directing and facilitating the students in the learning process to create more conducive process. 
The interview result showed that thematic learning plan has been arranged well. The mathematic material involving pi number has been given to the fifth-grade students in the first semester with the theme "My Environment" and subtheme "Surrounding Environment". This can be shown in the interview transcript.

$R$

: "How many sub themes appear in the circle material?"

PST : "The theme My Environment and subtheme Surrounding Environment."

$R \quad$ : "How do you teach circle material in class?"

PST : "I use lesson plan for the thematic learning. But mathematics subject has special lesson plan because it is not integrated with other subjects. I give the formula and also give some questions to do my students."

The learning process consisted of three steps that are opening, whilst, and closing activities. The process did not occur instantly, but passed through some certain steps. The teachers facilitated the students to study well. This interaction created effective teaching and learning process as expected. Teaching and learning process is a concrete form of education process. All elementary and tertiary educational institutions should be interactive, inspiring, enjoy, portable, challenging and motivating the students to be active in developing their skills and interests as well as their physical and psychological states [68].

Elementary schools to higher education would only be effective when they are organized by professional teachers. Good education is the result of teachers' success as the key of education itself [69][73]. The effective teaching tends to not only transfer knowledge from teachers to students. The teachers are expected to not only keep the learning process going on and give useful information spontaneously, but also learn more complicated materials and use them to develop the students' skills [74]-[76]. Mathematics is frequently considered to be related to number, space, measurement, calculation procedure, and construction or measuring that are applicable in wider scope. It is not seen as the way of thinking on concept, process and its application, problem exploration and its solution, hypothesis making and examination, and complex ideas about something communicate simply and appropriately.

The inhibiting factor in mathematics learning, especially in Pi $(\pi)$ number, in elementary schools could be seen in many points of views. The first is the teacher's point of view. The teacher that had designed lesson plan easily and only taken from internet sources that had been done by other teachers considered the lesson plan as complementary. The teacher's inability in renewing and doing mathematics learning principles made the learning implementation, especially in $\mathrm{Pi}(\pi)$ number, less developed. In addition, the teachers in teaching mathematics, especially in $\mathrm{Pi}(\pi)$ number, had often simplified the way of teaching and used teaching and learning steps that were not innovative. They only explained that Pi $(\pi) 3.14$. Based on the interview result, the teachers had low understanding on $\mathrm{Pi}(\pi)$ number that affected their way of teaching.

This mistaken concept of Pi $(\pi)$ number would be delivered to next generations when the teaching and learning activity does not involve scientific process. Tools in teaching and learning affect the students' learning outcome [77]. Based on observation, the teachers did not use any media. They only explained that Pi $(\pi)$ number is 3.14. The students only memorized it and applied it to exercises on circle area or circumference. The second is the students' point of view. Based on the interview result, the students said that mathematics is difficult and having many to memorize that made it less interesting. Mathematics is about abstract thing, and its basic object is about fact, concept, principles, skills, and its use in daily life. The low quality in mathematics learning will affect the students' learning outcome. Less various media and less interesting teaching and learning activity would make the students have lack interest in Pi $(\pi)$ number Furthermore, Pi $(\pi)$ number in decimal, 3.14, would complicate the students when it is applied in a formula and while it is only memorized. Nevertheless, teaching Mathematics in elementary schools is not easy. The students are in concrete operational phase. Additionally, they have various levels of ability.

There were some supporting factors in the teaching and learning activity of Pi $(\pi)$ number in elementary schools. One of them was the teacher's competence. The teachers are in productive age that could help to fix the mistaken concept in Pi $(\pi)$ number. The teachers' knowledge is the key in pi number teaching and learning. In addition, the students who live in millennial era would affect the teaching strategy used. An effective and efficient plan would be significant in Pi $(\pi)$ number teaching and learning in elementary schools. The curriculum designed by government is the reference to develop the teaching and learning activity in elementary schools that is adjusted to each school. The supports of students' parents contribute to better quality of teaching and learning. Trainings and workshops are regular programs for teachers. Nevertheless, it has no significant effect on Pi $(\pi)$ number teaching and learning. 


\section{CONCLUSION}

Pi $(\pi)$ number teaching and learning in Teacher Professional Program is interesting due to the findings on its implementation, inhibiting and supporting factors. The implementation showed that the teachers had lack understanding of $\mathrm{Pi}(\pi)$ number concept. It affected the plan in teaching and learning that was simple and not innovative. The absence of media in the Pi $(\pi)$ number teaching and learning process made the students less interested. The students considered mathematics as difficult and boring lesson. The teacher only explained that $\mathrm{Pi}(\pi) 3.14$ or $\frac{22}{7}$ that made the students only memorized it. In fact, at this age, the studetns have to think concretely. It became inhibiting factor in $\mathrm{Pi}(\pi)$ number implementation. The supporting factor in $\mathrm{Pi}(\pi)$ number teaching and learning is that there is curriculum designed by the government that becomes reference. The other supporting factor was the millennial students that were able to innovate the learning.

Pi $(\pi)$ number learning should be more contextual. Pi $(\pi)$ number could be introduced by surrounding objects contextually. This practice needs to be done by teachers and students, so they could construct their knowledge about Pi $(\pi)$ number in elementary schools.

\section{REFERENCES}

[1] V. Cruceanu, P. Fortuny, and P. M. Gadea, “A survey on paracomplex geometry," Rocky Mountain Journal of Mathematics, vol. 26, no. 1, pp. 83-115, 1996, doi: 10.1216/rmjm/1181072105.

[2] A. Einstein, Geometry and experience. Springer, Berlin, 1921.

[3] G. Lakoff and R. Núñez, Where mathematics comes from, vol. 6. New York: Basic Books, 2000.

[4] Y. Roza, P. Yuanita, S. Saragih, H. Alfajri, and A. Saputra, "Computer-Based Media for Learning Geometry at Mathematics Class of Secondary Schools," Journal of Educational Sciences, vol. 1, no. 1, pp. 79-91, 2017.

[5] E. A. Burroughs and J. L. Luebeck, "Pre-service teachers in mathematics lesson study," The Mathematics Enthusiast, vol. 7, no. 2, pp. 391-400, 2010.

[6] M. S. Hannula, R. Kaasila, A. Laine, and E. Pehkonen, "Structure and Typical Profiles of Elementary Teacher Students' View of Mathematics," Paper presented at the Conference of the International Group for the Psychology of Mathematics Education, 2005, vol. 3, pp. 89-96.

[7] A. Jaffe and F. Quinn, "Theoretical mathematics': toward a cultural synthesis of mathematics and theoretical physics," Bulletin of the American Mathematical Society, vol. 29, no. 1, pp. 1-13, 1993.

[8] C. C. Lewis and R. R. Perry, "A randomized trial of lesson study with mathematical resource kits: Analysis of impact on teachers' beliefs and learning community," in Large-scale studies in mathematics education. Springer, Cham, 2015, pp. 133-158.

[9] N. P. Rahmawati and M. Dintarini, "Implementation of Patil Lele Traditional Game As Ethnomathematics to Improve Student's Perspective to Mathematics," Mathematics Education Journal, vol. 3, no. 2, pp. 130-138, 2020.

[10] R. Crouch and C. Haines, "Mathematical modelling: Transitions between the real world and the mathematical model," International Journal of Mathematical Education in Science and Technology, vol. 35, no. 2, pp. 197-206, 2004.

[11] T. Dreyfus, "Advanced mathematical thinking processes," in Advanced mathematical thinking. Springer, Dordrecht, 2002, pp. 25-41.

[12] N. Mercer and C. Sams, "Teaching children how to use language to solve maths problems," Language and Education, vol. 20, no. 6, pp. 507-528, 2006.

[13] R. H. Austing, B. H. Barnes, D. T. Bonnette, G. L. Engel, and G. Stokes, "Curriculum'78: recommendations for the undergraduate program in computer science-a report of the ACM curriculum committee on computer science," Communications of the ACM, vol. 22, no. 3, pp. 147-166, 1979.

[14] S. B. Bush and K. S. Karp, "Prerequisite algebra skills and associated misconceptions of middle grade students: A review," The Journal of Mathematical Behavior, vol. 32, no. 3, pp. 613-632, 2013.

[15] P. Balakrishnan, "The Programme for International Student Assessment (PISA) in Southeast Asia: Media Reception in English-language Publications and Projection in National Education Policies," Ph.D. Thesis, Loyola University Chicago, 2019.

[16] K. Laksono and P. Retnaningdyah, "Literacy Infrastructure, Access to Books, and the Implementation of the School Literacy Movement in Primary Schools in Indonesia," in IOP Conference Series: Materials Science and Engineering, vol. 296, no. 1, pp. 1-9, 2018.

[17] S. Nugrahanto and D. Zuchdi, "Indonesia PISA Result and Impact on The Reading Learning Program in Indonesia," International Conference on Interdisciplinary Language, Literature and Education (ICILLE 2018), vol. 297. 2019.

[18] M. Tohir, Indonesia's PISA Results in 2018 are Lower than 2015, (in Indonesia). 2019, doi: 10.17605/OSF.IO/8Q9VY.

[19] R. Amiati, M. Sukaryawan, and E. Nawawi, "Analysis of the chemical science literacy skills of junior high school students in the city of Palembang in solving PISA model questions," (in Indonesia), Ph.D. Thesis, Sriwijaya University, 2021.

[20] P. Grootenboer and B. Hemmings, "Mathematics performance and the role played by affective and background factors Peter Grootenboer and Brian Hemmings," Math. Educ. Res. J., vol. 19, no. 3, pp. 3-20, 2007. 
[21] M. D. Darmawan and N. H. Dagamac, "Situation of Environmental Education in Senior High School Programs in Indonesia: Perspectives from the Teachers of Palembang," Interdisciplinary Journal of Environmental and Science Education, vol. 17, no. 3, pp. 1-8, 2021.

[22] P. A. Kamil, S. Utaya, D. H. Utomo, A. W. Abdi, and S. Ridha, "An Evaluation of Changes to The Secondary School Geography Curriculum in Indonesia Disaster Risk Reduction Effort," IOP Conference Series: Earth and Environmental Science, vol. 630, no. 1, 2021.

[23] L. H. Wijaya and M. Sholeh, "Evaluation of 2013 Curriculum Implementation in Economic Learning Class XI in Madrasah Aliyah Dakwah Islamiyah Putra Nurul Hakim Kediri West Lombok," Edunesia: Jurnal Ilmiah Pendidikan, vol. 2, no. 1, pp. 93-103, 2021.

[24] M. Pulungan and M. V. A. Suganda, "Need Analysis of Instruments Assessment of Curriculum 2013 Based on Higher Order Thinking Skills (HOTS) for Elementary School Students," in 4th Sriwijaya University Learning and Education International Conference (SULE-IC 2020), 2020, pp. 269-274.

[25] E. Chell and R. Athayde, "Planning for uncertainty: soft skills, hard skills and innovation," Reflective Practice, vol. 12, no. 5, pp. 615-628, 2011.

[26] R. De Villiers, "The incorporation of soft skills into accounting curricula: preparing accounting graduates for their unpredictable futures," Meditari Accountancy Research, Vol. 18, No. 2, pp. 1-22, 2010.

[27] M. Fadlillah, Implementation of the 2013 curriculum in elementary/MI, junior high/MTS, \& high school/MA learning, (in Indonesia). Yogyakarta: Ar-Ruzz Media, 2014.

[28] D. Ahmad, "Understanding the 2013 curriculum of English teaching through the teachers' and policymakers' perspectives," International Journal of Enhanced Research in Educational Development (IJERED), vol. 2, no. 4, pp. 6-15, 2014.

[29] I. Gunawan, "Indonesian Curriculum 2013: Instructional management, obstacles faced by teachers in implementation and the way forward," in 3rd International Conference on Education and Training (ICET 2017), 2017, pp. 56-63.

[30] F. Sodik and M. S. Wijaya, "Implementing scientific approach of 2013 curriculum at KTSP-based school for teaching present continuous tense," English Education: Jurnal Tadris Bahasa Inggris, vol. 10, no. 1, pp. 16-28, 2017.

[31] M. Graciella and E. Suwangsih, "The application of a realistic mathematical approach to improve students' mathematical representation skills," (in Indonesia), Metoda Didaktik, vol. 10, no. 2, pp. 27-36, 2016, doi: 10.17509/md.v10i2.3180.

[32] D. S. N. Afifah, "The interaction of students' learning mathematics in STAD cooperative learning," (in Indonesia), Pedagogia: Jurnal Pendidikan, vol. 1, no. 2, pp. 145-152, 2012, doi: 10.21070/pedagogia.v1i2.37.

[33] M. A. Rasyid, "Reflective thinking profile of junior high school students in solving fractional problems reviewed from gender differences," (in Indonesia), Kreano, Jurnal Matematika Kreatif-Inovatif, vol. 8, no. 2, pp. 171-181, 2017, doi: 10.15294/kreano.v8i2.9849.

[34] S. Somawati, "The role of self efficacy on mathematical problem solving ability," (in Indonesia), Jurnal Konseling dan Pendidikan, vol. 6, no. 1, pp. 39-45, 2018, doi: 10.29210/118800.

[35] J. Fairweather, "Linking evidence and promising practices in science, technology, engineering, and mathematics (STEM) undergraduate education," Board of Science Education, National Research Council, The National Academies, Washington, DC, 2008.

[36] C. A. Riedesel and L. Pikaart, "Focus on research: The role of attitudes in learning mathematics," The Arithmetic Teacher, vol. 16, no. 8, pp. 631-640, 1969.

[37] I. S. Horn, "Fast kids, slow kids, lazy kids: Framing the mismatch problem in mathematics teachers' conversations," The Journal of the Learning Sciences, vol. 16, no. 1, pp. 37-79, 2007.

[38] K. Litster, B. MacDonald, and J. F. Shumway, "Experiencing active mathematics learning: Meeting the expectations for teaching and learning in mathematics classrooms," The Mathematics Enthusiast, vol. 17, no. 2, pp. 615-640, 2020.

[39] M. Y. Mazana, C. S. Montero, and R. O. Casmir, "Assessing students' performance in mathematics in Tanzania: the teacher's perspective," Int. Electron. J. Math. Educ., vol. 15, no. 3, pp. 1-28, 2020.

[40] K. Weber, K. Lew, and J. P. Mejía-Ramos, "Using expectancy value theory to account for individuals' mathematical justifications," Cognition and Instruction, vol. 38, no. 1, pp. 27-56, 2020.

[41] D. A. G. Ramírez, Artificial Mathematical Intelligence. Springer International Publishing, 2020.

[42] D. S. Nahdi, M. G. Jatisunda, U. Cahyaningsih, and V. Suciawati, "Pre-service teacher's ability in solving mathematics problem viewed from numeracy literacy skills," Elementary Educ. Online, vol. 19, no. 4, pp. 1902$1910,2020$.

[43] J. T. Remillard and O.-K. Kim, "A framework for analyzing elementary mathematics curriculum materials," in Elementary mathematics curriculum materials. Springer, Cham, 2020, pp. 1-25.

[44] A. D. Utami and C. Sa'dijah, "Six Levels of Indonesian Primary School Students' Mental Model in Comprehending the Concept of Integer.," International Journal of Instruction, vol. 11, no. 4, pp. 29-44, 2018.

[45] M. J. Burke and D. L. Taggart, "So That's Why 22/7 Is Used for Pi!" The Mathematics Teacher, vol. 95, no. 3, pp. 164-169, 2002.

[46] D. S. Janorkar, "True Value of Pi $(\pi)$ Now is 3.141592653 we Call This as Goba Constant we Symbolic it as This Goba, This Letter," International Journal of Mathematics Trends and Technology, vol. 59, no. 1, pp. 27-34, 2018.

[47] J. Mišutka and L. Galamboš, "Extending full text search engine for mathematical content," Towards Digital Mathematics Library. Birmingham, United Kingdom. Masaryk University, 2008, pp. 55-67. 
[48] N. Backhouse, "79.36 Pancake Functions and Approximations to $\pi$," The Mathematical Gazette, vol. 79, no. 485, pp. 371-374, 1995.

[49] F. Beukers, "A rational approach to pi," Nieuw archief voor wiskunde. Serie 5, vol. 1, no. 4, pp. 372-379, 2000.

[50] D. H. Clements, J. Sarama, M. E. Spitler, A. A. Lange, and C. B. Wolfe, "Mathematics learned by young children in an intervention based on learning trajectories: A large-scale cluster randomized trial," Journal for Research in Mathematics Education, vol. 42, no. 2, pp. 127-166, 2011.

[51] J. De Lange, "Using and applying mathematics in education," in International handbook of mathematics education. Springer, Dordrecht, 1996, pp. 49-97.

[52] W. Glänzel and C. de Lange, "A distributional approach to multinationality measures of international scientific collaboration," Scientometrics, vol. 54, no. 1, pp. 75-89, 2002.

[53] J. B. Nebe, F. Luethen, R. Lange, and U. Beck, "Interface interactions of osteoblasts with structured titanium and the correlation between physicochemical characteristics and cell biological parameters," Macromolecular bioscience, vol. 7, no. 5, pp. 567-578, 2007.

[54] K. Gravemeijer and D. van Eerde, "Design research as a means for building a knowledge base for teachers and teaching in mathematics education," The Elementary School Journal, vol. 109, no. 5, pp. 510-524, 2009.

[55] H. A. A. van Eerde, "Design research: Looking in to the heart of mathematics education," Proceeding of the first South-East Asian Design Research Conference, 2013, pp. 1-11.

[56] C. M. Zubainur, R. Johar, R. Hayati, and M. Ikhsan, "Teachers' understanding about the characteristics of realistic mathematics education," Journal of Education and Learning (EduLearn), vol. 14, no. 3, pp. 456-462, 2020.

[57] D. W. Ekowati and B. I. Suwandayani, "Understanding the concept of $\pi$ numbers for elementary school pre-service teachers on circle materials," Jurnal Prima Edukasia, vol. 8, no. 1, pp. 12-19, 2020.

[58] K. Y1ldırım, "Raising the quality in qualitative research," Elementary Educ. Online, vol. 9, no. 1, pp. 79-92, 2010.

[59] N. Golafshani, "Understanding reliability and validity in qualitative research," The Qualitative Report, vol. 8, no. 4, pp. 597-607, 2003.

[60] S. Mathison, "Why triangulate?" Educational Researcher, vol. 17, no. 2, pp. 13-17, 1988.

[61] D. Carnine, "Instructional design in mathematics for students with learning disabilities," Journal of Learning Disabilities, vol. 30, no. 2, pp. 130-141, 1997.

[62] M. Abramowitz, I. A. Stegun, and R. H. Romer, Handbook of mathematical functions with formulas, graphs, and mathematical tables. American Association of Physics Teachers, 1988.

[63] D. L. Ball, Research on teaching mathematics: Making subject matter knowledge part of the equation, 1988. [Online]. Available: https://files.eric.ed.gov/fulltext/ED301467.pdf.

[64] I. Mueller, Philosophy of Mathematics and Deductive Structure of Euclid's Elements. Cambridge, Massachusetts and London: MIT Press 1981.

[65] D. M. S. F. Gaudiot and L. B. Martins, "The Classroom Built Environment as an Inclusive Learning Process for the Deaf Students: Contribution of Ergonomics in Design," in International Conference on Applied Human Factors and Ergonomics, 2018, pp. 531-540.

[66] R. Griffiths, "Knowledge production and the research-teaching nexus: The case of the built environment disciplines," Studies in Higher Education, vol. 29, no. 6, pp. 709-726, 2004.

[67] U. Iyer-Raniga and M. M. Andamon, "Transformative learning: Innovating sustainability education in built environment," International Journal of Sustainability in Higher Education, vol. 17, no. 1, pp. 105-122, 2016.

[68] B. I. Suwandayani, Y. Fakhruddin, and L. S. Astutik, "Implementation of the numeracy literacy program in learning mathematics remaining class IV in Muhammadiyah Elementary Schools," Proceeding Universitas Muhammadiyah Surabaya, 2020.

[69] R. D. Anderson, "Reforming science teaching: What research says about inquiry," Journal of Science Teacher Education, vol. 13, no. 1, pp. 1-12, 2002.

[70] R. B. Barr and J. Tagg, "From teaching to learning-A new paradigm for undergraduate education," Change: The Magazine of Higher Learning, vol. 27, no. 6, pp. 12-26, 1995.

[71] M. Cochran-Smith and M. K. Fries, "Sticks, stones, and ideology: The discourse of reform in teacher education," Educational Researcher, vol. 30, no. 8, pp. 3-15, 2001.

[72] L. Darling-Hammond, "Constructing 21st-century teacher education," Journal of Teacher Education, vol. 57, no. 3, pp. 300-314, 2006.

[73] A. Moore, The good teacher: Dominant discourses in teaching and teacher education. Psychology Press, 2004.

[74] B. Cerbin, The Nature and Development of Informal Reasoning Skills in College Students, 1988. [Online]. Available: https://files.eric.ed.gov/fulltext/ED298805.pdf.

[75] J. Elander, K. Harrington, L. Norton, H. Robinson, and P. Reddy, "Complex skills and academic writing: a review of evidence about the types of learning required to meet core assessment criteria," Assessment \& Evaluation in Higher Education, vol. 31, no. 1, pp. 71-90, 2006.

[76] G. S. Pratama and H. Retnawati, "Urgency of higher order thinking skills (HOTS) content analysis in mathematics textbook," Journal of Physics: Conference Series, vol. 1097, no. 1, pp. 1-31, 2018.

[77] A.-M. Nortvig, A. K. Petersen, and S. H. Balle, "A literature review of the factors influencing e-learning and blended learning in relation to learning outcome, student satisfaction and engagement," Electronic Journal of Elearning, vol. 16, no. 1, pp. pp. 46-55, 2018. 